\title{
The necessity of natural theology? In conversation with John Calvin on the human senses
}

\begin{abstract}
This contribution explores John Calvin's position on natural theology. The point of departure is not so much the much discussed notions of a sensus divinitatis or of the semen religionis, but the role played by the human senses in coming to knowledge of God in the first place. How can God's presence be recognised? How can human language (that which is natural), from below, express the inexpressible? How is it possible to speak of God in the first place? This article suggests that Calvin's remarkably sophisticated understanding of signification is the clue to respond to these questions. His position is discussed on the basis of the reading strategy of catena and commentary. The author finally offers some concluding observations on the relationship between signifier, signified and referent in human language about God.
\end{abstract}

\section{CALVIN AND “NATURAL" THEOLOGY?}

I do not wish to claim Calvin's support for the position on natural theology constructed in the previous essay. Nevertheless, Calvin was evidently not oblivious to the hermeneutical problem of coming to knowledge of God. He was also aware how intertwined the Christian faith is with other forms of knowing. Instead, I will structure this contribution as a conversation with Calvin, realising that others may be overhearing the conversation. The aim of this contribution is not so much to engage in reconstructive work on Calvin's position, but to test this thesis in conversation with Calvin's views on the role played by the human senses. My intention is to make a contribution to reformed discourse on natural theology, but also to bring insights from Calvin's Institutes into play in the context of contemporary discourse on natural theology.

To explore Calvin's position on "natural theology" is to open a proverbial can of worms. Both Brunner (2002:35-50) and Barth (2002:94-109) appealed to Calvin to support their respective positions and criticised each other's reading of Calvin. I cannot hope to review or contribute to the voluminous Calvin scholarship with regard to his position on natural theology, or his notions of "accommodation" and of the semen religionis. Suffice it to say that his position is difficult to interpret since it is embedded in deeply intertwined theological contrasts between what is called "general and "special" revelation, between the knowledge of God and of ourselves and in the metaphor that Scripture provides us with the necessary spectacles to see God in the world of nature. Furthermore, all of these terms are influenced by theological positions on the relation between nature and grace.

Here I will not explore such a notion of "natural theology", that is, of knowledge of the triune God that may be derived from a contemplation of "nature" excluding God's revelation in Jesus Christ. Instead, my focus will be on the question whether Calvin's position on knowledge of God as Mediator (in Jesus Christ) can be affirmed if one maintains that all theology may be

1 Prof EM Conradie, Professor, Department of Religion and Theology, University of the Western Cape,

Private Bag X17, Bellville 7535. E-mail: econradie@uwc.ac.za. 
regarded as natural theology (as proposed above). More specifically, how can one hear with human ears God's word of forgiveness as indeed God's word? My focus will therefore be on Calvin's understanding of the role of the human senses, especially seeing and hearing, and the visual imagery that he employs.

For the sake of simplicity I will adopt here the style of catena and commentary and supplement that with some concluding observations.

\section{CALVIN ON THE POSSIBILITY OF LANGUAGE ABOUT GOD?}

a) "Without knowledge of self there is no knowledge of God: Nearly all the wisdom we possess, that is to say, true and sound wisdom, consists of two parts: the knowledge of God and of ourselves. But, while joined by many bonds, which one precedes and brings forth the other is not easy to discern." (I.1.1).

The famous opening sentence of Calvin's Institutes has elicited much discussion. I remember one night in my student years when I set out to read the Institutes and could not get beyond the first sentence. The creative tensions and antithetical structures that are so typical of Calvin's theology and rhetoric are nowhere more evident than here. I do not wish to comment on his understanding of the knowledge of God as piety (reverence) or on his own emphasis that "without knowledge of God there is no knowledge of self" (the title of I.1.2). Instead, his awareness of the hermeneutical tension is important for my purposes here. The argument of the very first section is that the knowledge of ourselves, "the feeling of our own ignorance, vanity, poverty, infirmity, and - what is more - depravity and corruption" leads us to seek God. But how is such knowledge of our misery possible? Calvin insists "man is never sufficiently touched and affected by the awareness of his lowly state until he has compared himself with God's majesty" (I.1.3). Given the human inclination towards self-delusion, self-admiration and flattery (II.1.2) such knowledge of human misery cannot be gained merely through introspection. Here too the knowledge of God seems to be the key to the knowledge of the self. Nevertheless, he does not resolve the tension all that easily; it remains "strangely ambiguous", resisting textual closure (Jones 1995:87, 94). This is indicated by the closing sentence of I.1.3: "Yet, however the knowledge of God and of ourselves may be mutually connected, the order of right teaching requires that we discuss the former first, then proceed afterward to treat the latter." What this "order of right teaching" amounts to can only be discerned from the structure of the entire Institutes. In I.15.1 he does return to this topic. Observing that "This knowledge of ourselves is twofold: namely, to know what we were like when we were first created and what our condition became after the fall of Adam." The knowledge of ourselves is therefore not based on introspection or on social analysis but on witness of Scripture. For the moment it may suffice to observe that Calvin is not unaware of the hermeneutical tension at play here. Indeed, knowledge of God is connected to knowledge of ourselves and, one may add, of our world.

b) "There is within the human mind, and indeed by natural instinct, an awareness of divinity. This we take to be beyond controversy. To prevent anyone from taking refuge in the pretence of ignorance, God himself has implanted in all men a certain understanding of his divine majesty" (I.3.1).

This is Calvin's equally famous and much debated notion of semen religionis. Calvin insists that "from the beginning of the world there has been no region, no city, in short, no household, that could do without religion, there lies in this a tacit confession of a sense of deity inscribed in the hearts of all" (I.3.1). Even idolatry provides ample proof of this sense of the divine. In words that pre-empt the critique of religion of Marx and Lenin by several centuries he adds that "it is 
utterly vain for some men to say that religion was invented by the subtlety and craft of a few to hold the simple folk in thrall by this device and that those very persons who originated the worship of God for others did not in the least believe that any God existed" (I.3.2). Calvin eagerly concedes that forms of religion can be employed to strike common folk with terror, but insists that this would not be possible if our minds "had not already been imbued with a firm conviction about God, from which the inclination toward religion springs as from a seed" (I.3.2).

The question is what role this sense of the divine plays in obtaining knowledge of the triune God. The point of Calvin's argument is, of course, that any such knowledge is corrupted through ignorance and malice, that this cannot lead to true knowledge of God (since zeal for religion is not sufficient on its own - I.4.3) and that such "seed of religion" only serves to render us without the excuse of ignorance. Yes, the seed remains (there is some sense of divinity) and cannot be uprooted, but by itself produces only the worst fruits (I.4.4). It enables people to find sprinklings, droplets of truth. Whatever truth is seen in this way cannot and does not direct one to the truth (of God's favour) and does not enable one to attain it (II.2.18). In Book III Calvin also insists that there is no "seed of election" (a religious gene?), as if some are more inclined than others to piety and the fear of God (III.24.10). God's election is appropriated through God's call and this comes to human beings from outside themselves. However, the question remains whether this seed of religion plays any hermeneutical role in obtaining knowledge of the triune God? This question is less easy to answer since Calvin "does not investigate psychologically or metaphysically the nature of the act of cognition" (Parker 1995:14)!

c) "... wherever you cast your eyes, there is no spot in the universe wherein you cannot discern at least some sparks of his glory. You cannot in one glance survey this most vast and beautiful system of the universe, in its wide expanse, without being completely overwhelmed by the boundless force of its brightness. The reason why the author of The Letter to the Hebrews elegantly calls the universe the appearance of things invisible [Heb. 11:3] is that this skilful ordering of the universe is for us a sort of mirror in which we can contemplate God, who is otherwise invisible" (I.5.1).

The seed of religion is not only sown in the human mind; God is revealed in the glory of creation so much so that no one can open his or her eyes without being compelled to see God (I.5.1). The divine wisdom is displayed for all to see (I.5.2) - in the fields of astronomy, medicine, the natural sciences and structure of the human body (humanity as a microcosm) and of course also in history and in signs of God's providence. That this is evidently not seen or misunderstood has to do with humans being blindfolded, not with being blind. ${ }^{2}$ This has led us to confuse creatures with the Creator. Calvin employs his considerable rhetorical skills to heap up adjectives to describe such ungratefulness, stupidity, malice, wickedness, corruption, vanity, superstition, idolatry and hypocrisy. Thus the abundant evidence of God in the created order is to no avail (I.5.11). The manifestation of God in nature speaks to us in vain (I.5.14). Although they bathe us wholly in their radiance, they cannot lead us towards the right path to find the knowledge of God.

d) "Just as old or bleary-eyed men and those with weak vision, if you thrust before them a most beautiful volume, even if they recognize it to be some sort of writing, yet can scarcely construe two words, but with the aid of spectacles will begin to read distinctly; so Scripture, gathering up the otherwise confused knowledge of God in our minds, having dispersed our dullness, clearly

2 See also Calvin's comment: "But although the Lord represents both himself and his everlasting Kingdom in the mirror of his works with very great clarity, such is our stupidity that we grow increasingly dull toward so manifest testimonies, and they flow away without profiting us." (I.5.11). 
shows us the true God" (I.6.1).

Calvin uses the often-discussed image of "spectacles" to argue that Scripture is needed as guide and teacher in order to come to knowledge of God as Creator. Note that the image is reversed here: we do not need spectacles to read Scripture; we need the spectacles of Scripture to detect God's presence in nature (see Parker 1952:25f). This is, for example, reiterated in the work of Herman Bavinck (see 2003:340f) who followed Calvin closely in this line of argumentation. It should also be noted that Calvin insists that Scripture is required both for knowledge of God as Saviour and of God as Creator. The way in which Calvin distinguishes between the themes of creation and redemption is controversial (to say the least) as this also guides the structure of the entire institutes. For the moment it would suffice to note that the spectacles of Scripture are required in order to gain knowledge of God as Creator and to prevent us from seeking the creator in other deities through devious paths. The problem is not that we cannot see (that we are totally blind), but that we are short-sighted - that we cannot see clearly without the reading aid of Scripture (a point disputed by Parker 1952:39). We need not only eyes to contemplate God's works but also ears to hear God's Word (I.6.2). Without Scripture we fall into error (I.6.3).

It should be noted that the contemplation of God's works therefore does not necessarily direct us away from God's revelation in Jesus Christ; to know God in Jesus Christ redirects our attention towards the works of God - which supports and confirms the knowledge of God in Christ. God's Word provides us with the "spectacles" to heal our sight in order to see God's glory. As Schreiner (1991:107) puts it: "The noetic effect of sin is gradually corrected when the soul is reordered so that once again the cosmos can serve as a 'stage', 'theatre', or 'book' from which believers are encouraged to learn about their Creator." Reading the scripture does not replace or guide us away from contemplation of nature, but provides us with the spectacles precisely in order to engage in such contemplation (Zachman 2006:196). From the Bible we find the clues to identify God's presence in our own experience, in history, in creation and also amongst other faith traditions. As Postema (1992:429) suggests: "Obviously, the Bible does add to our knowledge of God ... but it does so only to clarify and untangle the cloudy and confused knowledge of God that we get from extra-biblical sources, to restore it to its original function."

On this basis it is also important to note that, for Calvin, this knowledge of God as Creator logically comes first. Unlike for Von Rad and others, knowledge of God as Creator is no mere extrapolation of faith in God as Saviour. Calvin says: "First in order came that kind of knowledge by which one is permitted to grasp who that God is who founded and governs the universe. Then that other inner knowledge was added, which alone quickens dead souls, whereby God is known not only as the Founder of the universe and the sole Author and Ruler of all that is made, but also in the person of the Mediator as the Redeemer" (I.6.1). He concludes "knowledge of God, otherwise quite clearly set forth in the system of the universe and in all creatures, is nonetheless more intimately and also more vividly revealed in his Word" (I.10.1). Here he comes close to but does not actually grant that such knowledge of God derived from the contemplation of nature also provides as with some preunderstanding that influences our reading of Scripture for better or for worse.

e) "Certainly I do not deny that one can read competent and apt statements about God here and there in the philosophers, but these always show a certain giddy imagination. As was stated above, the Lord indeed gave them a slight taste of his divinity that they might not hide their impiety under a cloak of ignorance. And sometimes he impelled them to make certain utterances by the confession of which they would themselves be corrected. But they saw things in such a way that their seeing did not direct them to the truth; much less enable them to attain it! They are like a traveller passing through a field at night who in a momentary lightning flash 
sees far and wide, but the sight vanishes so swiftly that he is plunged again into the darkness of the night before he can take even a steplet alone be directed on his way by its help. Besides, although they may chance to sprinkle their books with droplets of truth, how many monstrous lies defile them!" (II.2.18).

A number of aspects in this remarkable passage may be noted. Of course, Calvin's primary intention here is to emphasise that the knowledge of God that may be derived from the (philosophical) contemplation of nature is severely limited. It cannot even begin to imagine God's mercy and benevolence towards us. It provides no right knowledge of God but renders humans without any excuse for not obtaining such knowledge by claiming ignorance (II.2.22). Yet, Calvin's favoured visual imagery is striking. Human beings are blindfolded by sin but we are not blind. We cannot see because of the darkness of the night, but are indeed able to see flashes of light - but this is not sufficient to guide us on our way. Without the illumination of the Spirit we remain in darkness. As Calvin eloquently adds, "the sun rises upon the earth when God's Word shines upon men; but they do not have its benefit until he who is called the "Father of lights" [James 1:17] either gives eyes or opens them. For wherever the Spirit does not cast his light, all is darkness" (II.2.21).

Again, nature provides us with the eyes to see; that we in fact do not see is the result of being blindfolded. Here too Calvin stops short of exploring the hermeneutical significance of such an ability to see when seeing the light (when reading Scripture). His emphasis is clearly on the gift of God's revelation and illumination and not on the human ability to understand. Without the Light of the world shining upon us, we would not see, even if we were able to see. To focus on our seeing (which Calvin seems to take for granted) would misdirect the attention away from the guidance that we require when hopelessly lost in the dark of a cloudy night.

f) "Indeed, if we chose to explain in a fitting manner how God's inestimable wisdom, power, justice, and goodness shine forth in the fashioning of the universe, no splendour, no ornament of speech, would be equal to an act of such great magnitude. There is no doubt that the Lord would have us uninterruptedly occupied in this holy meditation; that, while we contemplate in all creatures, as in mirrors, those immense riches of his wisdom, justice, goodness, and power, we should not merely run over them cursorily, and, so to speak, with a fleeting glance; but we should ponder them at length, turn them over in our minds seriously and faithfully, and recollect them repeatedly. But because our purpose here is to teach, it is proper for us to omit those matters, which require long harangue. Therefore, to be brief, let all readers know that they have with true faith apprehended what it is for God to be Creator of heaven and earth, if they first of all follow the universal rule, not to pass over in ungrateful thoughtlessness or forgetfulness those conspicuous [sic] powers which God shows forth in his creatures, and then learn so to apply it to themselves that their very hearts are touched. The first part of the rule is exemplified when we reflect upon the greatness of the Artificer who stationed, arranged, and fitted together the starry host of heaven in such wonderful order that nothing more beautiful in appearance can be imagined; who so set and fixed some in their stations that they cannot move; who granted to others a freer course, but so as not to wander outside their appointed course; who so adjusted the motion of all that days and nights, months, years, and seasons of the year are measured off; who so proportioned the inequality of days, which we daily observe, that no confusion occurs. It is so too when we observe his power in sustaining so great a mass, in governing the swiftly revolving heavenly system, and the like. For these few examples make sufficiently clear what it is to recognize God's powers in the creation of the universe. Otherwise, as I have said, if I decide to set forth the whole matter in my discourse, there will be no end" (I.14.21).

One may regard this passage as one of the clearest examples in Calvin's Institutes of what 
would elsewhere be deemed a form of natural theology. However, it should be noted that Calvin here focuses on knowledge of God as Creator, that his account is deliberately brief in order to avoid speculation, that he insists that Scripture is necessary to understand such knowledge of God as Creator clearly (as discussed above) and that the brevity of his account here should be compared with his elaborate discussion of knowledge of God as Redeemer.

In my view the true significance of this passage can only be grasped within the context of his theology as a whole - in the interplay between the themes of creation, sin, providence, redemption and the eschatological restoration of all things. Susan Schreiner (1991:121) is on the right track here: "As the perceptual breakdown caused by sin is healed through the Spirit and Scriptures, nature regains its revelatory function as a mirror, a painting, and a theatre of the divine glory." In terms of the metaphor of being blindfolded that Calvin is so fond of, the natural ability to see is restored through redemption. It is not that we are given completely new eyes by listening to the Word of God. The Word helps us to see once again that which was before our eyes all the time. It removes the blindfold imposed by sin so that we can indeed see. As John McNeill (1960:liii) comments in his introduction to the Institutes, "Yet men [sic] are so damaged by the heritage of sin entailed by Adam's fall that they miss this testimony of creation to the Creator, and grope blindfold in this bright theatre of the universe with only erroneous and unworthy notions of the God who made it."

Another metaphor that Calvin is fond of is that of the mirror. In the passage quoted above creatures are portrayed as mirrors of the immense riches of God's wisdom. The universe is the mirror in which we can contemplate the invisible God (I.5.1). This is portrayed with "very great clarity" (I.5.11). Humankind is also a clear mirror of God's works (I.5.3). This also applies to the ministry of angels (I.14.5). Elsewhere Calvin uses the image with reference to God's law as a mirror for the knowledge of $\sin (I I .7 .6,7)$, with reference to Scripture as a source of the knowledge of our human arrogance (II.2.11, II.3.2), but also of the knowledge of God (III.2.6), and especially with reference to the incarnation of Jesus Christ as a bright mirror of God's boundless love (II.12.4, II.14.7) and his resurrection as a mirror of Christ's divinity (II.16.13). Elsewhere he speaks of faith as an act of seeing our future inheritance as if in a mirror (II.11.1), even though we see that now only dimly (1 Cor 13:12).

Here too Calvin consistently maintains visual imagery. The problem is not that we are blind but that we cannot see the image that we are looking at clearly. The problem is not that the image is too dim but that it is too bright - we therefore require a dimmed, reflected image of God, accommodated to our human sensibilities (Battles 1998:36). The clarity and focus of the image is only found on the basis of Jesus Christ, Scripture and the illumination of the Holy Spirit through Christian proclamation. The Spirit corrects the noetic effect of sin and enables the pious contemplation of nature as the mirror, the theatre of God's glory (Schreiner 1991:122). This is consistent with Calvin's insistence throughout the Institutes that nothing falls outside the sphere of God's sovereignty. Our ability to see and to understand is not ignored or even downplayed; it is acknowledged and restored but only through God's grace. If Calvin did not acknowledge the hermeneutical role of such natural knowledge in reading Scripture and hearing God's Word, he might have taken that simply for granted.

In his work "As in a mirror" (Als in een Spiegel) Cornelis van der Kooi (2002:58-64) explores the metaphor of seeing an image in a mirror as the clue to Calvin's understanding of knowledge of God (better: of knowing God). The point of the image is of course that we can know God only in a mediated way (by way of imitation), namely through God's reflection in God's works (including the heavens above, but also humanity, the incarnation and the full range of other traces of God's presence). The possibility of seeing a reflection in the mirror is not so much a function of human capabilities but of that, which is, reflected in the mirror, namely God self. This possibility, 
one may surmise, is a function of God's accommodatio. For Calvin the metaphor suggests that knowledge of God is not a matter of abstraction or demonstration but of immediate and intuitive knowledge (cognitio intuitiva). It is a direct form of knowledge based on the recognition of God's immediate presence, albeit the presence of a mirror image of lesser quality and not a direct visio Dei. Van der Kooi notes that mirrors in Calvin's day were made of plated metal allowing for a reliable but somewhat dimmer reflection than what is possible though glass mirrors nowadays. The reliability of the image is for Calvin crucial because it dovetails with his affirmation of the clarity of Scripture and of assurance of salvation. It is thus important to emphasise that knowing God requires from us to look at those mirrors in which God's is most clearly reflected. The image of God in the pond (God's non-human creation) is muddied by human sin, whereas the clearest image may be found in Jesus Christ and in the contemporary context through the sacraments (see below). At the same time it metaphor of a mirror image suggests that one should not focus on the possibilities of the mirror itself (although the mirror is indeed necessary), or on the image in the mirror but on the Person whose image is reflected. That can only be understood by way of following the direction towards which a sign points. This is only possible through the guidance of the Holy Spirit who uses the mirror images to establish communion between God and humans on this basis (Van der Kooi 2002:63).

g) "To sum up: When first even the least drop of faith is instilled in our minds, we begin to contemplate God's face, peaceful and calm and gracious toward us. We see him afar off, but so clearly as to know we are not at all deceived. Then, the more we advance as we ought continually to advance, with steady progress, as it were, the nearer and thus surer sight of him we obtain; and by the very continuance he is made even more familiar to us. So we see that the mind, illumined by the knowledge of God, is at first wrapped up in much ignorance, which is gradually dispelled. ... Thus, bound with the fetters of an earthly body, however much we are shadowed on every side with great darkness, we are nevertheless illumined as much as need be for firm assurance when, to show forth his mercy, the light of God sheds even a little of its radiance" (III.2.19).

In his discussion of the nature of faith Calvin emphasises that faith is based on knowledge, not ignorance, superstition or gullibility (III.2.2-3). Yet, faith as knowledge far exceeds human sense perception. It is not merely derived from a human capacity to understand. The knowledge of faith, Calvin insists, "consists in assurance rather than in comprehension" (III.2.14). Its certainty is based on the Word of God and more specifically on the sealed promises of God.

At the same time, faith is not independent of human sense perception but works through it. The Spirit works through the letter not alongside that. In the passage quoted above it is remarkable to observe the use of visual imagery. Faith is a matter of light and of sight, albeit that the emphasis in not on the human ability to see, but on the object that is seen and on the light that is cast to make such seeing possible. The problem, one may add, is not so much a lack of light but that the light is so overwhelming that we are blinded by it (see Hesselink 1997:48). God accommodates God self according to our human capacity so that we can measure God's immeasurableness by our small measure (Balzerak 2008, Battles 1998:35).

However, faith is more than seeing, it perceives the invisible, the not yet visible. Here, Calvin argues, faith needs the assurance of God's Word in order to take root and to bear fruit. Whatever we may see of God's presence and might is fleeting and would vanish without the confirmation of God's Word. This does not arise out of anyone's imagination (III.2.31). Calvin tirelessly explains that such faith is a gift from God that it is the work of the Holy Spirit that ensures that the seed of the Word becomes implanted, that faith depends on the promise of grace and that its certainty is not based on the strength of faith but on the promises that are sealed by God's signature. Yet, none of this takes place outside the human senses of seeing and hearing and even of "tasting 
the truth" (III.2.33). In fact, the interplay between the senses is remarkable. With reference to Isaiah 40-45 Calvin remarks:

It often seems that, when he begins to speak concerning the hope of pardon and reconciliation, he turns to something else and wanders through long and superfluous mazes, recalling how wonderfully God governs the frame of heaven and earth together with the whole order of nature. Yet there is nothing here that does not serve the present circumstance. For unless the power of God, by which he can do all things, confronts our eyes, our ears will barely receive the Word or not esteem it at its true value (III.2.31).

Clearly, salvation through faith takes place in the realm of the (human) creature, making use of human capacities. Salvation hermeneutically presupposes God's creation, that which is natural and thus transforms it. Nevertheless, the imagery that Calvin deploys is remarkable in that it consistently avoids the impression that faith may be attributed to the human ability to see and to hear. Faith is the result of the object that becomes visible through the light that is cast on the object. Likewise, hearing is not the product of our fertile imagination but is primarily based on the Word of promise and forgiveness that is addressed to us. Indeed, Calvin insists that that we are blind (and deaf) in this respect. "The Word of God is like the sun, shining upon all those to whom it is proclaimed, but with no effect among the blind ... it cannot penetrate into our minds unless the Spirit, as the inner teacher, through his illumination makes entry for it" (III.2.34). Moreover, the problem is not so much our lack of perception: "the heart's distrust is greater than the mind's blindness" (III.2.36). That is why faith can only follow from the assurance of the Word that seals God's promises in our hearts so that we become assured of God's mercy. Yet, it is our hearts and minds (that which is "natural") that become thus assured. The object that becomes visible and the word that is heard remains within this world; within that which is "natural".

h) In his discussion of the Lord's Prayer in Book III.20.40 Calvin discerns the hermeneutical implications of such insights. Why, he asks, is the Father understood to be "in heaven"? Calvin is well aware that the Father cannot be crudely or literally positioned in the heavens, for the heavens cannot contain God. Indeed, God cannot be "confined to any particular region but is diffused through all things." Calvin then adds:

But our minds, so crass are they, could not have conceived his unspeakable glory otherwise. Consequently, it has been signified to us by "heaven," for we can behold nothing more sublime or majestic than this. While, therefore, wherever our senses comprehend anything they commonly attach it to that place, God is set beyond all place, so that when we would seek him we must rise above all perception of body and soul. ... Therefore it is as if he had been said to be of infinite greatness or loftiness, of incomprehensible essence, of boundless might, and of everlasting immortality. But while we hear this, our thought must be raised higher when God is spoken of, lest we dream up anything earthly or physical about him, lest we measure him by our small measure, or conform his will to our emotions. At the same time our confidence in him must be aroused, since we understand that heaven and earth are ruled by his providence and power (III.20.40).

This remarkable statement gets to the core of the hermeneutical problem of the knowledge of God. How can one know that which transcends oneself if it is indeed transcendent? How may the imperceptible be perceived? Calvin rightly sees that "heaven" here functions as the best available symbol of that which is sublime and majestic. This is a form of synecdoche where the part points beyond its immediate meaning in order to symbolise the whole (see Battles 1998:3940). He also sees that God's transcendence cannot be confined to a particular location, but is diffused everywhere. However, this does not lead to a vague form of pantheism. The clue here is 
that this prayer is taught to us by Jesus Christ and is prayer in the name of Christ. This is indeed the location where the traces of God's transcendence may best be found. In this way God is both exalted and very near to us (see Baars 2009, Smit 2009:70).

At the same time this qualitative assessment would not suffice on its own. The later Barthian emphasis, namely that God may be found in Jesus Christ and that the divinity of Christ does not merely say something about Christ but about the identity and character of God, addresses only one half of the hermeneutical problem. The question remains how we could say of Jesus of Nazareth that a manifestation of God's presence may be found here? Why and how could one claim that Jesus is anything more than an ordinary human being? What does it mean that Jesus is "truly God" (vere Deus)? ${ }^{3}$ The question thus returns: How can one even speak about God? Moreover, how can one speak on God's behalf with any degree of authority? How would one know that one's words about God are more than just that: one's own constructions about God?

The answer to the hermeneutical question is, of course, quite simple, namely that the point of departure is indeed that which can be perceived. The knowledge of God does not come from above but from below. It is derived from that which is natural. Hence, all theology is natural theology. This is not nullified by Calvin's seemingly Neo-Platonic insistence that in seeking God "we must rise above all perception of body and soul." Rising above perception (whatever that may mean) is only possible on the basis of perception. What is required are traces of God's presence, intimations of transcendence, a sense of the infinite in the finite - even if the finite cannot contain the infinite (the famous extra Calvinisticum). The Christian claim is that such traces may best be found in Jesus Christ and perhaps nowhere more clearly than in this prayer.

i) "We are not here discussing whether a human ministry is necessary for the sowing of God's Word, from which faith may be conceived. This we shall discuss in another place (IV.1.5). But we say that the Word itself, however it be imparted to us, is like a mirror in which faith may contemplate God." (III.2.6)

God's word is proclaimed through human instruments so that we would be able to hear that. Calvin is not merely stating the obvious here. He is arguing against a residual Gnosticism and Manichaeism, which maintain that fallible human instruments can only drag down the authority of the Word. Instead, Calvin argues, one should be grateful that God has opted to "consecrate to himself the mouths and tongues of men in order that his voice may resound in them" (IV.1.5). Spiritualising fanatics (Anabaptists), by contrast, may claim more immediate access to God's will, but thus refuse to hold unto God's word. It is on this basis that Calvin offers an elaborate discussion of the significance of Christian ministry, which, he maintains, remains primarily a ministry of God's word, that is, a word of mercy and forgiveness (IV.1-13).

j) "Here our merciful Lord, according to his infinite kindness, so tempers himself to our capacity that, since we are creatures who always creep on the ground, cleave to the flesh, and, do not think about or even conceive of anything spiritual, he condescends to lead us to himself even by these earthly elements, and to set before us in the flesh a mirror of spiritual blessings. For if we were incorporeal (as Chrysostom says), he would give us these very things naked and incorporeal. Now, because we have souls engrafted in bodies, he imparts spiritual things under visible ones" (IV.14.3).

3 Pannenberg (1991:68) rightly insists that "The designation of Yahweh as God and the Christian attributing of deity to Jesus Christ make sense only on the condition of an established pre-Christian and extra-Christian use of the word 'God'." He adds the Christian restriction of this general category obviously implied a correction to the connotations attached in extra-Christian use. This suggests a defect in Barth's understanding of the revelation in Christ. The latter presupposes that the world belongs to God and that humanity knows the God who is proclaimed by the gospel, even though a wholly new light is shed on this knowledge by the revelation in Christ (1991:75). 
Calvin's famous treatment of the notion of a sacrament is of direct relevance for my exploration of the way in which that which is natural may serve as a carrier of God's word of forgiveness. Following Augustine, Calvin defines a sacrament as "an outward sign by which the Lord seals on our consciences the promises of his good will toward us in order to sustain the weakness of our faith" (IV.14.1). He insists that the sign is meaningless without the word - which has to explain the meaning of the sign. The purpose of the sign is to confirm and seal the promises of God.

Calvin develops this insight in two crucial further steps. He first argues that the material signs are by themselves worthless and nothing more than water, bread and wine. They are sacraments ("visible words") only in terms of that which they signify - which is explained through the Word. He says: "Indeed, the believer, when he sees the sacraments with his own eyes, does not halt at the physical sight of them, but by those steps (which I have indicated by analogy) rises up in devout contemplation to those lofty mysteries which lie hidden in the sacraments" (IV.14.5). The human senses are required in order to hear the word and to see the signs, but these signs are mere "mirrors in which we may contemplate the riches of God's grace" (IV.14.6). The purpose of the sacraments is only to come to our aid to ascertain the trustworthiness of God's promises.

The next step is to emphasise that the sacraments do not have any secret powers to impart God's grace. They become effective only through the illumination of the Holy Spirit. Only in this way do the sacraments help to establish and enhance faith in the heart of the believer - thus "[our] hearts are penetrated and affections moved and our souls opened for the sacraments to enter in" (IV.14.9). And; "For, that the Word may not beat your ears in vain, and that the sacraments may not strike your eyes in vain, the Spirit shows us that in them it is God speaking to us, softening the stubbornness of our heart, and composing it to that obedience which it owes the Word of the Lord. Finally, the Spirit transmits those outward words and sacraments from our ears to our soul" (IV.14.10).

Calvin then adds:

If the Spirit be lacking, the sacraments can accomplish nothing more in our minds than the splendour of the sun shining upon blind eyes, or a voice sounding in deaf ears. Therefore, I make such a division between Spirit and sacraments that the power to act rests with the former, and the ministry alone is left to the latter-a ministry empty and trifling, apart from the action of the Spirit, but charged with great effect when the Spirit works within and manifests his power (IV.14.9).

Calvin acknowledges that the human eye would not see anything, nor would the ear be struck by any noise, unless they were created and fitted for seeing and hearing (IV.14.9). His argument in this section is not that the senses are worthless without the word that is heard and the object that is seen (see above). Instead, he draws a complex analogy between such natural capabilities, which are necessary to hear and to perceive, and the necessity of the work of the Holy Spirit in our hearts, "which is to conceive, sustain, nourish, and establish faith". Without such illumination the sacraments would be worthless. Intriguingly, Calvin then adds: "There is only this difference: that our ears and eyes have naturally received the faculty of hearing and seeing; but Christ does the same thing in our hearts by special grace beyond the measure of nature" (IV.14.9). How should this "special grace beyond the measure of nature" be understood? Although one may suspect an unresolved Platonism here, one may also explore the relationship between a sign and that which it signifies (see below), precisely in order to take the human senses (and the letter of the law) as serious as Calvin does. For Calvin, it is through the Word of God that such connotations are attached, engraved upon the material signifier: "When they were inscribed by God's Word a new form was put upon them, so that they began to be what previously they were not" (IV.14.18). The sacraments confirm and seal that which is promised through the Word; it "effectively performs what it symbolizes" (IV.15.14). 
Calvin applies this emphasis on signs and what they signify to the meaning of each of the sacraments. On the Lord's Supper he says for example: "our souls are fed by the flesh and blood of Christ in the same way that bread and wine keep and sustain physical life. For the analogy of the sign applies only if souls find their nourishment in Christ-which cannot happen unless Christ truly grows into one with us, and refreshes us by the eating of his flesh and the drinking of his blood" (IV.17.10). This quotation illustrates how the signification of signs is interpreted here along the dualisms of matter and ideas, of body and soul - albeit that the signified (human thoughts, ideas, that which is "spiritual"), although invisible, remains "natural" in the sense outlined above.

What is being signified can only be understood through the power of the Holy Spirit. Calvin says:

Even though it seems unbelievable that Christ's flesh, separated from us by such great distance, penetrates to us, so that it becomes our food, let us remember how far the secret power of the Holy Spirit towers above all our senses, and how foolish it is to wish to measure his immeasurableness by our measure. What, then, our mind does not comprehend let faith conceive: that the Spirit truly unites things separated in space (IV.17.10). I therefore say (what has always been accepted in the church and is today taught by all of sound opinion) that the sacred mystery of the Supper consists in two things: physical signs, which, thrust before our eyes, represent to us, according to our feeble capacity, things invisible; and spiritual truth, which is at the same time represented and displayed through the symbols themselves (IV.17.11).

These observations calls for further reflection on Calvin's theory of signs (and of symbols ${ }^{4}$ ), on the relation between what Saussure would later call the (material) signifier and the (ideal) signified, but also between a sign and its referent. In terms of the use of the term "natural" above, the signified (as embedded in human thought processes) remains a function of cultural evolution and is in that sense "natural". The relation between sign and referent is far trickier. Can a sign refer to extra-linguistic realities - even when it is acknowledged that our only access to such a referent is mediated through language? Is human language a self-enclosed world? Can human language refer to God (a transcendent referent)?

These questions cannot be resolved here and Calvin's semiotics would require closer investigation. Suffice it to say that Calvin severely criticised the failure to distinguish between a sign and that which it signifies. He ridicules notions of transubstantiation precisely on this point (IV.17.14-30). He distinguishes between the "signification" (the promises of God), the matter or substance that is signified (Christ's death and resurrection) and the effect that follows from both ("redemption, righteousness, sanctification, and eternal life, and all the other benefits Christ gives to us") (IV.17.11). The last of these are understood pneumatologically and calls for further reflection in the discipline of hermeneutics, not only semiotics.

k) "It is not what is seen, then, but what is believed, that feeds" (IV.17.3, in a discussion of Augustine's position).

One last comment on the unresolved dualisms in Calvin's theology remains important here. The contrast between that which is visible and that which is invisible may be regarded as

4 Calvin recognised the distinction between signs and symbols (where the symbol participates in that which it symbolises). He says: "For though the symbol differs in essence from the thing signified (in that the latter is spiritual and heavenly, while the former is physical and visible), still, because it not only symbolizes the thing that it has been consecrated to represent as a bare and empty token, but also truly exhibits it, why may its name not rightly belong to the thing?" (IV.17.21). Following Augustine, Calvin thus concludes that sacraments have a certain likeness to those things of which they are sacraments. Otherwise they would not be sacraments at all (IV.17.21). 
unproblematic. It would, incidentally, also appeal to contemporary African sensibilities. Likewise, one need not assume a Platonic or Cartesian dualism between the ideal and the material to distinguish between brain functions and thought, between signifier and signified. However, Calvin often juxtaposes this contrast with the ones between soul and body, the carnal and the spiritual, this earth and heaven, ${ }^{5}$ this life and eternal life. The sign is material and visible and differs "in essence" from the reality that is signified - which is not only invisible but also "spiritual" and "heavenly" (IV.17.21).

It should be noted that this contrast is built upon cosmological assumptions (see Schreiner 1991:7-37). The problem that Calvin addresses in his discussion of the sacraments is in what way Christ's body, which is in heaven (see IV.17.26), could be present in the symbol of the bread? Calvin insists that Christ's body is finite and remains in heaven, giving weight to the meaning of Christ's ascension (IV.17.27. It therefore does not require a feigned miracle to make his body present (across a "great distance in space") in the elements of sacrament (IV.17.26). It is ludicrous to consider two bodies of Jesus Christ - one visible in heaven and one hidden in secret under bread (IV.17.28). One can guard against such crude, superstitious and literalist notions by recognising the distinction between a sign and what it signifies. Christ becomes present primarily through the symbols and though the power of the Holy Spirit - through which God "pours down his grace from heaven through the Spirit upon us" (IV.17.28). Yet, the unresolved dualism in Calvin's theology cannot be denounced as merely Platonic as he also insists that in his resurrection Jesus Christ received the same true flesh as when he was born from the virgin Mary, that it is Christ's body that is in heaven, and that the hope for the resurrection of our bodies and (interestingly enough) for our ascension into heaven is based on that (IV.17.29). Accordingly, we need not "drag" Christ down from heaven; we may hope to be "lifted up" to him (IV.17.30).

From a contemporary perspective such weight attributed to the ascension of course does not resolve the cosmological problem. How may we fathom the distinction between earth and heaven? How did Calvin come to know about that which is "heavenly" (except by following the biblical vocabulary)? How can our words refer to (make present) that which transcends the natural? In short, how can our human words refer to God? How can we speak with any authority about God and God's word to us?

The unresolved hermeneutical and cosmological problem is well illustrated by the following: Once more I wish to warn my readers to consider diligently the purport of our doctrine: whether it depends upon common sense or, having surmounted the world on the wings of faith, soars up to heaven. We say Christ descends to us both by the outward symbol and by his Spirit, that he may truly quicken our souls by the substance of his flesh and of his blood. He who does not perceive that many miracles are subsumed in these few words is more than stupid. For nothing is more beyond the natural than that souls should borrow spiritual and heavenly life from a flesh that had its origin from earth, and underwent death. There is nothing more incredible than that things severed and removed from one another by the whole space between heaven and earth should not only be connected across such a great distance but also be united, so that souls may receive nourishment from Christ's flesh (IV.17.24).

5 Calvin distinguishes between "earthly" and "heavenly" things in the following way: "I call "earthly things' those which do not pertain to God or his Kingdom, to true justice, or to the blessedness of the future life; but which have their significance and relationship with regard to the present life and are, in a sense, confined within its bounds. I call 'heavenly things' the pure knowledge of God, the nature of true righteousness, and the mysteries of the Heavenly Kingdom. The first class includes government, household management, all mechanical skills, and the liberal arts. In the second are the knowledge of God and of his will, and the rule by which we conform our lives to it" (II.2.13). 
The preceding discussion has illustrated that Calvin was certainly not unaware of the hermeneutical problem of coming to knowledge of God (understood by him in terms of faith as piety, that is, as reverence, awe and trust). It is obvious that he emphasised that any "natural" knowledge of God, unaided by the witnesses of Scripture is severely limited and distorted due to the legacy of human sin, therefore cannot lead to adequate knowledge of God and only suffices to preclude human excuses on the basis of ignorance. What is less obvious is the role played by such human capacities, the human senses and our preceding vocabularies in order to come to "true" knowledge of God.

That we can actually hear the Word of God (the word of forgiveness) and that we can read the Scriptures can only be based on our "natural" capacities. However, that would be worthless without being confronted by the object that is seen and the word (the sound) that is heard. For Calvin, that word comes to us from outside our own capabilities. The heart of the matter lies in his insistence that the liberating word of God's forgiveness is not based on our merits, on our good works, on first becoming righteous before being declared righteous, on our penitence, or on our faith. It is based solely on God's mercy, on God's grace as expressed in the work of Christ, and, in the very final analysis, on God's election. Thus the emphasis is not on our hearing but on the word of forgiveness that is heard. Moreover, that word of forgiveness is precisely not merely a human word (that would imply that we are forgiving ourselves), but indeed God's word. But what could that mean?

This word of forgiveness does not come to us in some mysterious way. It is audible and tangible. The object that is seen and touched, the word that is heard, still forms part of our world (of "nature"). The bridge between the known and the unknown, the finite and the infinite is the Logos that was addressed to us and became flesh - visible, touchable, palpable (Battles 1998:24). ${ }^{6}$ It is a Word that is always already amongst us. This is communicated to us on the basis of the life and work of Jesus Christ, through the apostolic witnesses, the biblical texts, exegesis and proclamation. It is through the letter of Scripture that the word of forgiveness is spoken and heard. This is how God's mercy is made known to us. It is received through our human senses. As we have seen above, Calvin is very much aware of the role played by the senses and takes our "natural" capacities for granted.

God is therefore made known to us through the human senses. However, none of the objects of our senses would by themselves yield knowledge of God. Many people passing Jesus by on the road would see in him nothing more than another traveller. Many people today would hear in preaching nothing more than a speech delivered in a religious community. How, then, does something that is entirely "natural" convey the presence of God? How does that which is finite bear evidence of the infinite (even if the finite cannot contain the infinite)?

In the terminology of semiotics this begs complex questions about the ways in which signs and symbols function. What is the relation between a (material) signifier and a signified (the connotations attached to a signifier in human thought)? On the basis of the argument above, both the material signifier and the ideal signified remain part of "nature" and in that sense entirely "natural". That applies also to human thought patterns such as moral judgements and moral codes which are based on the assumption that what reality is, is not what it ought to be. Such judgements may seem to be other than "natural". To derive an "ought" from an "is" may even be regarded as falling in the trap of the naturalistic fallacy. However, in the sense that such moral codes are human constructs they form part of human cultural evolution and in that sense

6 See Battles (1998) on Calvin's rhetorical use of the strategy of accommodation: God accommodates himself according to human capacity. 
part of nature as defined above.

The problem becomes more complex in the case of religious language where the signified tends to transcend human thought, indicating something that we cannot grasp, suggesting intimations of transcendence, of God's presence. Moreover, how should the elusive relation between a sign and its referent be understood? Where such a referent is said to transcend human thought, this poses special difficulties. Indeed, how can one refer to God and God's word of forgiveness at all? In the case of symbols, which already contain what they signify, this relation between sign and referent becomes even more complex. The easy option would be to regard such theological language as nothing more than a human construction. This would be to base theological language on anthropology along the lines of modern liberal theology. As I argued above, this is hermeneutically inevitable, but to leave it at that would be reductionist. It would not do justice to the claim that the intended referent of such language expresses Someone who transcends "nature" by virtue of creating it in the first place.

Obviously, I cannot hope to resolve such complex questions here. In Calvin's terminology such intimations of transcendence are only possible on the basis of the illumination of the Holy Spirit through which faith takes root in the heart of the believer. Yet, such illumination is also not portrayed as something mysterious but as taking place through the exegesis of the meaning (the letter) of the text in order to appropriate its usefulness (the spirit) within the context of Christian piety (IV.8.13). I do wish to highlight the complex problem that this poses for a forensic notion of justification: how may it be said that the human word of forgiveness (which forms part of "nature") on the basis of what Christ has done (in the history of "nature") is ultimately God's word of forgiveness (without which there would be no consolation) in such a way that the basis for such forgiveness is not attributed to our own doing (our good works, our faith)? Can such tension between the sign (the signifier and the signified) and its transcendent referent be sustained?

Nevertheless, such a sense of transcendence can be articulated in human thinking, speaking and writing. As many contributors to discourse on science and religion have observed, the use of symbols is one of the distinctive features of the human species. Indeed, even though this is an area where angels should fear to tread, discussions of the transcendent (as signified or as transcendent referent) fill theological libraries. All too often theologians, including Calvin (and Barth!), tend to become remarkably sure about that which transcend us and speak with considerable authority about that. The ensnaring danger is to speak about God on God's behalf and with God's authority. ${ }^{7}$

One may retort that such a sense of authority is not focused on the signified but on the signifiers that are deemed to be carriers of God's presence. Accordingly, and speaking with Barth, the focus should be on the threefold word (of God), namely Jesus of Nazareth (the incarnation of the Logos), the biblical texts (Holy Scripture) and preaching (the Word of God). In my view

7 In my view this argument is nevertheless based on a failure to grasp the nature of religious language. When one engages with constructions of that which transcends "nature", it is not possible to maintain an objective distance from such a construction. One cannot view it as if from the outside precisely because such a construction is necessarily all-inclusive. Instead, one is urged to contemplate how the world would look like if its origin, destiny and meaning have to be understood in this light. One has to think, speak and live from within this universe of meaning. Typically, the mode of discourse then shifts to language about who God is, what God does and what God says - to the language of liturgy, preaching, paraenesis and doctrine. This may be sustained as long as the fragile nature of such discourse is recognised, as long as we acknowledge that we are attempting to give answers to questions that we have to ask but know that we cannot answer in any final way. Such language may form our last, ultimate words, the language of doxology (and of divine election), but cannot provide a firm foundation upon which an entire theological system may be built. 
that would be entirely appropriate. However, it should then be noted that such signifiers form part of the world around us and are in that sense "natural". Moreover, they are experienced in relation with other signifiers (in an ongoing differential play of signifiers which shape that which is signified) and through our senses and our preceding vocabularies. Any such theological language thus remains entirely human, fully natural.

One may, from another angle, re-describe the use of such signs as a function of God's accommodation to our human capacity (the notion of accommodatio Dei). As Battles (1998) and Balserak (2009:372) observe, Calvin paid more attention to such accommodation than any other theologian except Chrysostom. Accordingly, God revealed God self to us in such a way that we would be able to understand that. Such accommodation would apply to each aspect of the threefold word of God, but especially to the incarnation. However, such a re-description, too, has to be understood as an attempt to view human understanding from God's perspective. Such a perspective can only be obtained "from below", from within our capacities, from within that which is natural. It does not and cannot come directly "from above". How, one needs to ask, can one know that God decided on such accommodation? The key here, as Zachman (2006:209) recognises, is Calvin's analogical and anagogical understanding of the relations between a sign and the reality signified. Zachman describes this in terms of the visible images of the invisible God - in the theatre of God's glory, but also in terms of the cross of Christ. ${ }^{8}$

In recognising the role of an unresolved complexio oppositorum in Calvin's theology, it seems to me that the only way to capture Calvin's position is on the basis of a hermeneutical spiral. This spiral would move from the role of the human senses in order to gain knowledge of the world around us, which would provide some categories in terms of which the knowledge of God that emerges through an engagement with Scripture becomes possible, to the corrective role played by the Scriptures transform the connotations attached to such categories from within, in order to be able to see God's presence for the first time in the world around us with the help of the spectacles of Scripture and to contemplate the wonders of God's works. Crudely formulated: without contemplation of the heavens we would not have any notion of God; without God's revelation in Jesus Christ we would have no clarity on God's identity and no access to God's path for salvation. This suggest that human knowledge of the world around us does not merely have a negative function (as many commentators wish to emphasise), but plays a necessary hermeneutical role in order to be able to hear the Word of God or to read the Scriptures in the first place. Moreover, the purpose of Scripture is to provide the spectacles to detect God's presence in God's works. The spectacles are not required to read Scripture, nor are we to be preoccupied with reading the Scriptures. We require Scripture in order to appreciate the theatre of God's glory.

This does not imply that Calvin himself would have explained it in this way. Thomas (1992:135) may be on the right track in suggesting that Calvin simply does not concern himself with such a hermeneutical question: "He [Calvin] probably felt it too shrouded in mystery to warrant attention." Calvin's own view is perhaps best expressed in the following quotation picked up by Thomas (1992:136):

Therefore, as we cannot come to Christ unless the Spirit of God draws us, so when we are drawn we are lifted up in mind and heart above our understanding. For the soul, illumined by him, takes on a new keenness, as it were, to contemplate the heavenly mysteries, whose splendour had previously blinded it. And man's understanding, thus beamed by the light of the Holy Spirit, then at last truly begins to taste those things, which belong to the Kingdom of God,

8 On the distinction between images and living images and the dialectic between word and image, see especially Zachman (2007). 
having formerly been quite foolish and dull in tasting them (Institutes III.2.34).

\section{CONCLUDING OBSERVATIONS: THE (S)ELECTION OF SIGNIFIERS}

Perhaps the underlying problem here is not whether such signifiers are natural, whether they come to us from the inside or the outside (including the word of forgiveness), or whether they are enmeshed in a web of meanings and interpretations. The issue at stake here is the selection of signifiers, the privileging of some traces of God's presence above others. It may true that we can find traces of God's presence elsewhere, indeed everywhere, but the witness of the Christian tradition is that God's presence can be found more clearly than anywhere else in the narrative of Israel's notion of God, in the life and work of Jesus the Christ, and through witnesses to the presence of the Holy Spirit in and through the ministry and mission of Christian churches. This can only be understood as a qualitative judgement, namely that these sources offer us the clearest available traces of God's presence. These signifiers are carriers of a signified that can help us to come to terms with the origins, destiny and meaning of the history of the entire universe, of our own lives and of our struggles with the demands of life, with suffering and with the evil that surrounds us and for which we are partly responsible.

In my view this would require from reformed theology to rethink distinctions made between the so called "book of nature" and the "book of Scripture" or between "general revelation and "special revelation". Such distinctions become problematic the moment such categories are compartmentalised as two distinct sources for reflecting on God's self-revelation. Then questions on the relationship between these two sources immediately arise. In my book the "book of nature" and the "book of Scripture" cannot be understood as two distinct sources. "If "special revelation" forms part of nature, as I argued above, then it should be regarded as a qualitative judgement in terms of which some traces of God's self-revelation are selected on the basis of their relative clarity. The locus of special revelation forms part of the locus of general revelation. In diagram form one would need a circle (or a few dots and a cross) within a much bigger circle instead of two circles alongside one another. Or perhaps one may picture this three-dimensionally as a funnel: with a wide upper rim and a small inner tube that nevertheless exercises all the suction power. To express this more acutely: God's special revelation in Jesus Christ (but also through the history of Israel and in the early church) forms one moment in the history of the universe / the world / nature (and in the evolution of species) - even if one wishes to maintain retrospectively that the universe itself was created through the wisdom of the divine Logos.

On this basis the critique of natural theology would suggest that a particular theological position does not do justice to God's self-revelation in Jesus Christ because it seems to value other clues to God's revelation higher than that (see Barth 2002:74-5). However, any access to God's self-revelation in Jesus Christ can only be through categories derived from "nature"

In the same way the axiom of sola Scriptura requires reconsideration. It cannot be understood as the only source of the true knowledge of God, but it can be viewed as the best available source and can be used to judge other sources (Scripture as norm). However, such judgement cannot be exercised in a purist way since the biblical texts are embedded in a network of other "texts" and meanings, including pre-Israelite notions of God, and are interpreted through our existing vocabularies. It is therefore necessary to consider the inverse of Calvin's image that Scripture provides us with the necessary spectacles to see God in the world of nature. It is also true that nature provides us with the spectacles to read Scripture and to discern God's presence in and through the reading of the biblical texts.

To insist that all theology is natural theology may in this way encourage a sense of theological humility. It may help us to see that we are here attempting to answer ultimate questions that 
we cannot help but to raise, but know that we cannot answer, even if we have to live on a daily basis from the answers that we have received. It may help us to recognise that when we speak about God we can only do it from within the world of nature, from the humus where we came from and to which we shall return. Indeed, language about God can be nothing more than our last, final and ultimate words, the language of doxology.

\section{BIBLIOGRAPHY}

Baars, A 2008. Triniteit. In: Selderhuis, HJ (ed): The Calvin handbook, 245-257. Grand Rapids: WB Eerdmans. Balserak, J 2009. Accommodatio Dei. In: Selderhuis, HJ (red): The Calvin handbook, 372-378. Grand Rapids: WB Eerdmans.

Barth, K 2002 [1946]. No! An answer to Emil Brunner. In: Natural theology, 67-128. Eugene: Wipf \& Stock. Battles, FL 1998. God was accommodating himself to human capacity. In: McKim, DK (ed): Readings in Calvin's theology, 21-42. Eugene: Wipf \& Stock.

Bavinck, H 2003. Reformed dogmatics, volume 1: Prolegomena. Grand Rapids: Baker Academic.

Brunner, E 2002 [1946]. Nature and grace: A contribution to the discussion with Karl Barth. In: Natural theology, 15-64. Eugene: Wipf \& Stock.

Hesselink, IJ 1997. Calvin's first catechism. Featuring Ford Lewis Battles's translation of the 1538 Catechism. Louisville: Westminster John Knox Press.

Jones, S 1995. Calvin and the rhetoric of piety. Louisville: Westminster John Knox Press.

McNeill, JT 1960. Calvin: Institutes of the Christian religion (2 volumes). Louisville: Westminster John Knox Press.

Parker, THL 1952. The doctrine of the knowledge of God: A study in the theology of John Calvin. Edinburgh: Oliver and Boyd.

Parker, THL 1995. Calvin: An introduction to his thought. Westminster: John Knox Press.

Postema, GJ 1992. Calvin's alleged rejection of natural theology. In: Gamble, RC (ed): The organizational structure of Calvin's theology, 135-146. New York \& London: Garland.

Schreiner, S 1991. The theatre of his glory: Nature and the natural order in the thought of John Calvin. Grand Rapids: Baker Academic.

Smit, DJ 2009. The Trinity in the Reformed Tradition. Journal of Reformed Theology 3:1, 57-76.

Thomas, JN 1992. The place of natural theology in the thought of John Calvin. In: Gamble, RC (ed): The organizational structure of Calvin's theology, 147-176. New York \& London: Garland.

Van der Kooi, C 2002. Als in een spiegel: God kennen volgens Calvijn en Barth. Kampen: JH Kok.

Zachman, RC 2006. John Calvin as teacher, pastor and theologian: The shape of his writings and thought. Grand Rapids: Baker Academic.

Zachman, RC 2007. Image and word in the theology of John Calvin. Notre Dame: University of Notre Dame Press.

\section{KEY WORDS}

Calvin

Natural theology

Semiotics

Signification

\section{TREFWOORDE}

Calvyn

Natuurlike teologie

Semiotiek

Tekens 